\title{
A Study of Emile Durkheim's Concept of Anomie in Hubert Selby's Novel Requiem for a Dream
}

\author{
Najme Khodadadi ${ }^{1}$, Ensieh Shabanirad ${ }^{2}$ \\ ${ }^{1}$ M.A. Student of Language and English Literature \\ University of Semnan, Iran \\ ${ }^{2} \mathrm{PhD}$ Candidate of Language and English Literature \\ University of Tehran, Iran \\ E-mail address: \\ eshabanirad@gmail.com²
}

Keywords: Anomie, Durkheim, normlessness, society, values, Requiem for a Dream

\begin{abstract}
Emile Durkheim introduced the concept of anomie in the field of sociology for the first time. According to Durkheim anomie is equal with normlessness or detachment from social standards and values in society. Hubert Selby in his novel Requiem for a Dream depicts the theme of addiction which influences the life of four characters as a demonstration of the results of keeping distance from the norms. This paper intends to examine the relationship between anomic situation with disintegration and fall of idealism in Selby's novel from Durkheim's point of view.
\end{abstract}

\section{INTRODUCTION}

Anomie is defined in encyclopedia Britannica as "a condition of instability, resulting from a breakdown of standards and values or from a lack of purpose or ideals." Theory of anomie was proposed by Durkheim in his book Division of Labor but later he developed this idea in suicide. In the final chapter of Division of Labor Durkheim emphasized on the occupational rules and anomic division of labor in economic crisis as he explained about lack of solidarity in society that "it is because the relation of organs are not regulated, because they are in a state of anomy" (363). On the other hand, in his suicide Durkheim illustrates four types of suicide and argues the concept of anomie as a lack of social regulation when moral rules are simply confused or not presented. He also defines anomic suicide as a result of detachment from guiding norms and values which keep individuals together. Hubert Selby's novel Requiem for a Dream was written in1978 in New York and narrates the life of four addicts who are struggling to reach self- fulfillment and satisfaction by following their dreams. The novel starts when Harry is trying to take the TV set from his mother's house, Sara Goldfarb. She is a poor, lonely widow, and dependent on television and diet pills which are supposed to help her to stay young and beautiful. Her son is a university graduate, jobless and addicted and wants to starts a drug distributing business with his friend Tyrone. Marion is Harry's girlfriend who is an artist and also addicted to Heroin with which she finds creativity. These four characters live through a disappointed and disillusioned condition which at the beginning they think is a beautiful dream and something to live for but eventually ruins them. Based on the definition of anomie and anomic suicide which was discussed earlier there is mismatched behavior toward the norms in this novel where absence of standards and rules leads to the disruption between individuals and society, and the more they try to gain inspiration the more they fail. It seems that major cultural problems like addiction, consumption, and urgency of needs are regarded as normless and anomie that characters cannot see any legitimate means to achieve their goals according to established rules of society. As Robert King Merton one of the followers of Durkheim in sociological studies and anomie theory states in his social theory and social structure " aberrant behavior may be regarded sociologically as a symptom of dissociation between culturally prescribed aspiration and socially structured avenues for realizing these aspiration. "(Merton 188) This essay is aimed at analyzing the correlation between the concept of anomie in society, and also discusses the probable causes and outcomes of this anomic condition on the major events and actions of novel Requiem for a Dream. 


\section{CONCEPT OF ANOMIE AND Requiem for a Dream}

Requiem for a Dream is one of Selby's most powerful works, and an indelible portrait of the ravages of addiction. Harry and Tyron are minor Heroin consumers when the story begins but later on when they decide to start their own business they become addicted until their habits destroy their dreams. Same story happens for Harry's mother Sara when she receives a call from her favorite diet show which invites her to be a participant in future, so she becomes addicted to strong diet pills in order to be fit in her red dress.

According to Clinard and Meier ideas:

Norms can change over time, and some drugs not considered deviant at one time may open users to sanctions at another time. Most attitudes identifying drug use as deviance developed during 20th century. Prior to this time, U. S society widely tolerated drug use in many forms. During 19th century, people regarded drug addiction as a personal problem, generally pitying addicts rather than condemning them. Only later did addicts experience stigma of disreputable characters and addiction gain an association with criminal behavior. Changes public opinion and subsequent changes in the legal status of some drugs seem to have followed public acceptance of associations between drug use and disvalued people or lifestyle (227).

While deviance and addiction combine together the result would be very perilous and damaging which may lead to antisocial behavior, aggression, lying and disengagement as we can notice all of these happening in the actions of Harry and his girlfriend Marion when they ran out of money. Without money they cannot buy more drugs. Harry pleads Marion to ask Arnold for $\$ 2,000$ so that Harry and Tyrone would be able to make a purchase from a notorious mob figure. As Marion fears, Arnold wants her to sleep with him in return, and she reluctantly submits to Harry's acceptance. Harry's relationship with Marion begins to fall apart when the need for heroin starts to defeat their sensibilities and the love they have for each other. Marion blames Harold for the failed purchase from the mob figure.

In Social Theory and Social Structure, Robert Merton in discussing types of individual adaptation begins by addressing that there are five types of role behaving in society, and drug addicts are in Retreatism category as in his words:

In public and ceremonial life, this type of deviant behavior is most heartily condemned by conventional representatives of the society. In contrast to conformist, who keeps the wheels of society running, this deviance is non-productive liability in contrast to innovator who is at least "smart" and actively striving, he sees no value in success-goal which the culture prizes so highly; in contrast to the Ritualist who conforms at least to the mores, he pays scant attention to the institutional practices (208).

As Merton explained, there is a disconnection between goals and dreams of society and means to achieve them. These defined goals and dreams in most societies are referred to as wealth and material success and that happiness or satisfaction is equivalent to these goals.

As we see in this story each character succumbs to self-gratification, which eventually and inevitably leads to self-destruction. The four main characters, Harry Goldfarb, Sara Goldfarb, Marion, and Tyrone C. Love each suffer from individual addictions, be it their dreams, illegal, legal narcotics, or even television. "Ultimately not only their bodies and minds, but their very souls are destroyed by their addictions" (Giles 104).

In other words, though Harry and Tyrone wanted to be rich by selling heroin, but on the other hand adequate means to acquire these goals are not provided. Characters are reduced by the logic of consumerism to a debased and commodified vision of better living through increased consumption, whether it be of sex, food, drugs, or more conventional consumer goods. As Selby himself notes, "The dream I'm referring to in the book, of course, is the great American dream: prosperity, property, prestige, etc. And the fact that it'll kill you dead. Striving for it is a disaster. Attaining it is a killer. It takes many forms, and the results are not happy. It's not a feel-good thing". As Tyson puts it, "financial success is simply the product of initiative and hard work" and is attainable by "getting ahead," thus, signifying "competition" and "rugged individualism" (54). Selby 
demonstrates his characters following happiness through material gain, and Harry, Tyrone, Marion, and Sara experience horrible fates attempting to achieve their materialistic dreams.

In other words, the novel is approximately similar to naturalistic fiction, but varies in the sense of human agency. While there are certain environmental elements that lead Sara Goldfarb to her destruction (gender roles, television, and the McDick Corporation), it is her conscious decisions and obsessive desires that really cause her to lose her identity. In this sense, Selby is a harsh critic of American culture, who simultaneously does not let his characters be absolved from the conscious choices they make: "I suppose Selby must be thought of as a Christian novelist. The Wages of Sin, etc." (Metcalf 369).

Generally speaking, Hubert Selby is classified among those American authors, who in a forthright manner portray following perspective of leading a city life: solitude, isolation, and disillusionment. Obviously, his novel is involved with representing the interiority of his characters as they struggle with addiction. For instance Sara's addiction is television because of her "need" to identify with the housewife and motherly characters. But whereas Sara is fully enchanted with the act of watching television, the other characters Selby presents interact with television differently. It must be noted that while the other characters struggle with heroin addictions, Selby merely draws parallels between their addictions and Sara's. Like Sara's televisual experiences, the heroinaddicted characters use heroin as a "pleasurable," and temporary, escape from their current situations. Halfway through the novel, Sara's son suggests buying his mother a television as an act of love for her.

Additionally concerning where to situate Requiem for a Dream in the American canon, it is preferable to mention that it is a story about addiction, and not only to drugs, but also to television and food. Ultimately, Selby writes about characters that are addicted to "hoping" for a better life.

This idea is to some extent similar to Durkheim's definition of economic anomie in which he emphasized on formulation of industrial society based on economic value that affects non-economic environments like family relation, education and others. There are various different perspectives on what anomie is in this concept and how it is related to deviant behavior but from the given examples and illustration we can conclude that addiction as one of the main themes of this novel is a kind of deviant behavior and subset of anomie or breakdown between social rules of society.

Two major causes of anomie according to Durkheim are: the division of labor, and rapid social change. Both of these are associated with modernity. The division of labor is the specialization of cooperating individuals who perform specific tasks and roles. Having workers perform single or limited tasks eliminated the long training period required to train craftsmen, who were replaced with lesser paid but more productive unskilled workers. Historically, an increasingly complex division of labor is associated with the growth of total output and trade, the rise of capitalism, and of the complexity of industrialized processes.

As Durkheim mentions in his division of labor increasing division of labor weakens the sense of identification with the wider community and thereby weakens limitation on human behavior (213).

These conditions lead to social "disintegration", norm violation, and result to distrust of authority. According to Durkheim desires that human being hold inside themselves forces him to originate outside, in other words the more human being wants the more he tries to get, as in Durkheim words "there is nothing within an individual which constrains these appetites, they must surely be contained by some force exterior to him, or else they would become insatiable that is morbid" (Durkheim 199).

The second cause of anomie may be the result of rapid change in the structure of society. Durkheim mentions that as society becomes more complex and complicated, people in the community may have less engagement with social interest and norms; moreover, they have more tendency to do as individuals unlike previous communities which developed expense of common value, so they were more dependent on each other. In addition Durkheim reasoned that individuals are more problematic for their community. 
In Hubert Selby's novel, this division of labor is much more apparent in case of Harry and Tyrone than in Marion because she doesn't come from a low class of society, she owns her apartment and use drugs to be more creative, but in case of Harry things are quite different. He comes from a working class family, his mother is a simple housewife and we don't know much about his father but Selby characterize setting of the story as if his parents doesn't have too much money to support their son, so he is tempted to get rich by stealing his mother's television in order to start a business in heroin and get rich.

Tyrone who is portrayed as a young man with lots of flash backs to his memories with his mother when he felt safe near her, is also from working class of society and in the end of the story when he is in prison he suffers a lot from racism and loneliness. From these examples through novel we can understand that the causes of normlessness in this society may not be a sudden social change or anomic suicide. First of all when Selby wrote this novel, modernization and effects of it was done and American society was already on the right path to industrialization, secondly because anomic suicide which occur during the times of social and economic depression when people don't know how to achieve their goals did not happened here. Therefore we can conclude that effects of division of labor and also Merton's strain theory of anomie are the causes of this normlessness which is dominant in society.

As Buckeye states Selby's “characters discover they have no voice in the world, that their efforts to speak are frustrated, that no one listens, that at the end they are silenced and it is only their inner voice that compels our attention. That inner voice is Selby's testament" (375). For Selby's novel is a critique of capitalism gone awry. As James R. Giles puts it, Requiem for a Dream is about how "American society has become entrapped in the pervasive materialism of a ubiquitous capitalism, and such a world is closed to any healing or saving Grace"(Understanding, 112).

As Selby notes in one of his interview, "All of the people in my novels fail because of lack of control. Not because they are immoral by anybody's standards, but because they lost control. The lack of power is their dilemma"(315). In America's capitalistic, individualistic, consumer-based culture, the lack of love, control, or power will force any individual into searching for some means to happiness, whether it is television, food, drugs, or sex. This is what Selby's fiction is concerned with: the interior of American individuals as they obsessively search for happiness in a capitalistic society.

Failure of some parts of society to keep pace with other parts can cause dislocations or fragmentation of identity which result in anomie. As Durkheim says in his suicide one of the consequences of individuals insufficient relationship with society is anomic suicide. One of the reasons makes suicide rates increase as Durkheim observed in economic crisis is "Every disturbance of equilibrium, even though it achieved greater comfort and a heightening of general vitality, is an impulse to voluntary death"(246). No human being can be happy unless his needs are satisfied to its means; for if needs surpass its capacity to fulfill them, the result may only be friction, pain, lack of productivity, and a general weakening of the impulse to live. When society is disturbed by some crisis it will be temporarily incapable of exercising its regulative function and the lack of aspiration makes happiness impossible. This explains why periods of economic disaster, like those of sudden breakdown, are accompanied by an increased number of suicides, and also why countries long immersed in poverty have enjoyed a relative immunity to self-inflicted death. Along with Durkheim's ideas on the same subject Merton also observed that:

An effective equilibrium between these two phases of social structure is maintained so long as satisfaction accrue to individuals conforming to both cultural constraints. Satisfaction from the achievement of goals and satisfaction emerging directly from institutionally canalized modes of striving to attain them is reckoned in term of product and in terms of the process, in terms of outcome and in terms of activities (188).

Whenever this satisfaction as Merton points out is not fully gained by individuals their actions is not based on cultural or moral basis. In this story although nobody committed suicide as an act of killing, but all of four major characters failed to reach their dreams. The ideal fantasy world they had in their mind not only collapsed but also changed their lives fundamentally. 


\section{CONCLUSION}

From examining different aspects of anomie according to Durkheim in this novel, addiction is shown as a deviant behavior which is in contrast with norms of society. When individuals behave against dominant values or standards of society they are keeping their distance from unity of social relationships, so it may result in disintegration in society. In this novel we observed that at the beginning of story all characters had formed specific dreams for themselves for example Sara Goldfarb wanted to be fitted in her red dress and she was very proud of herself but at the end because of diet pills addiction and severe hallucination problem she ended up in mental hospital with several brain shocks. Her son Harry had lost his arm because of multiple heroin injections and convicted to years of prison with his friend Tyrone. Marion his girlfriend sold herself for heroin and as narrator describes at the end about what she was feeling "on her way home she had to fight hard to deny what she was feeling. She had been naive" (Requiem 118) all of these characters had fall from their idealistic world which they have been dreaming about. As argued here we can conclude in modern societies dissatisfaction to fulfill human being needs result in disintegration between people and society or as Durkheim called anomie. When people remain in state of anomie and move against values of current society they lose their idealistic vision for future as we observed in the novel by Hubert Selby.

\section{References}

[1] "Anomie | Sociology." Encyclopedia Britannica Online. Encyclopedia Britannica, 25 Nov. 2014. Web. 4 Jan. 2015. <http://www.britannica.com/EBchecked/topic/26587/anomie.

[2] Buckeye, Robert. "Some Preliminary Notes Towards a Study of Selby." The Review of Contemporary Fiction 1.2 (1981): 374-75.

[3] Clinard, Marshall B. Robert F Meier. Sociology of Deviant Behavior. 15th ed. Boston: Congage Learning, 1968. 227. Print.

[4] Durkheim, Émile. On Suicide. London: Penguin, 2005. Print

[5] Durkheim, Émile. The Division of Labor in Society. New York: Free of Glencoe, 1964. Print

[6] Giles, James R. "Hubert Selby, Jr." Dictionary of Literary Biography, Volume 227: American Novelists Since World War II, Sixth Series. Ed. James R. Giles and Wanda H. Giles. Northern Illinois: Gale, 2000.

[7] ---. Understanding Hubert Selby, Jr. Columbia: U of South Carolina P, 1998.

[8] Metcalf, Paul. "Herman and Hubert: The Odd Couple." The Review of Contemporary Fiction 1.2 (1981): 364-69.

[9] Merton, Robert King. Theory and Social Structure. New York: Free, 1949. 702. Print.Selby, Hubert. Requiem for a Dream. New York: Thunder's Mouth Press, 1978.print.

[10] Selby Jr., Hubert. Interview with Allan Vorda. "Examining the Disease: An Interview with Hubert Selby, Jr." Face to Face: Interviews with Contemporary Novelists. Ed. Allan Vorda. Houston: Rice UP, 1993. 185-210.

[11] ---. Interview with John O'Brien. “An Interview with Hubert Selby, Jr." The Review of Contemporary Fiction 1.2 (1981): 315-335.

[12] Tyson, Lois. Critical Theory Today: A User-Friendly Guide. New York: Routledge, 2006. Print. 